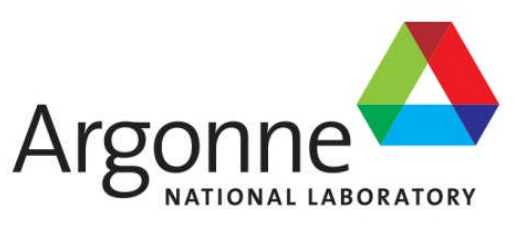

ANL/CSE-13/2

\title{
Column Optimization Studies
}

Chemical Science and Engineering Division 


\begin{abstract}
About Argonne National Laboratory
Argonne is a U.S. Department of Energy laboratory managed by UChicago Argonne, LLC under contract DE-AC02-06CH11357. The Laboratory's main facility is outside Chicago, at 9700 South Cass Avenue, Argonne, Illinois 60439. For information about Argonne and its pioneering science and technology programs, see www.anl.gov.
\end{abstract}

\title{
DOCUMENT AVAILABILITY
}

Online Access: U.S. Department of Energy (DOE) reports produced after 1991 and a growing number of pre-1991 documents are available free via DOE's SciTech Connect (http://www.osti.gov/scitech/)

Reports not in digital format may be purchased by the public from the National Technical Information Service (NTIS):

U.S. Department of Commerce

National Technical Information Service

5301 Shawnee Rd

Alexandra, VA 22312

www.ntis.gov

Phone: (800) 553-NTIS (6847) or (703) 605-6000

Fax: (703) 605-6900

Email: orders@ntis.gov

Reports not in digital format are available to DOE and DOE contractors from the Office of Scientific and Technical Information (OSTI):

U.S. Department of Energy

Office of Scientific and Technical Information

P.O. Box 62

Oak Ridge, TN 37831-0062

www.osti.gov

Phone: (865) 576-8401

Fax: (865) 576-5728

Email: reports@osti.gov

\footnotetext{
Disclaimer

This report was prepared as an account of work sponsored by an agency of the United States Government. Neither the United States Government nor any agency thereof, nor UChicago Argonne, LLC, nor any of their employees or officers, makes any warranty, express or implied, or assumes any legal liability or responsibility for the accuracy, completeness, or usefulness of any information, apparatus, product, or process disclosed, or represents that its use would not infringe privately owned rights. Reference herein to any specific commercial product, process, or service by trade name, trademark, manufacturer, or otherwise, does not necessarily constitute or imply its endorsement, recommendation, or favoring by the United States Government or any agency thereof. The views and opinions of document authors expressed herein do not necessarily state or reflect those of the United States Government or any agency thereof, Argonne National Laboratory, or UChicago Argonne, LLC.
} 
ANL/CSE-13/2

\section{Column Optimization Studies}

by

Amanda J. Youker, Pei-Lun Chung, Elizabeth Krahn, and George F. Vandegrift

Chemical Science and Engineering Division, Argonne National Laboratory

prepared for

U.S. Department of Energy, National Nuclear Security Administration,

Office of Defense Nuclear Nonproliferation

February 10, 2012 



\section{CONTENTS}

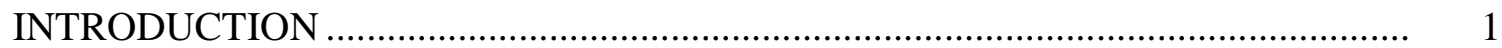

BATCH STUDIES: EXPERIMENTAL .............................................................. 2

2.1 Preparation of Mo-99 Spike Solution …….................................................. 2

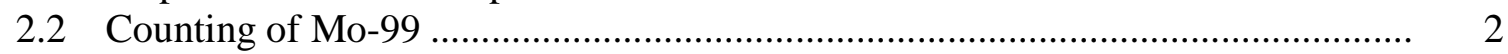

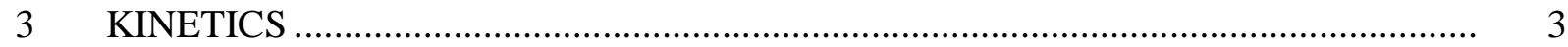

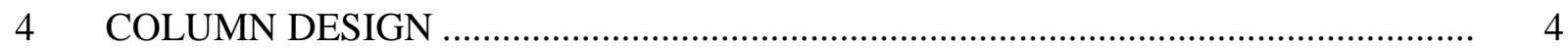

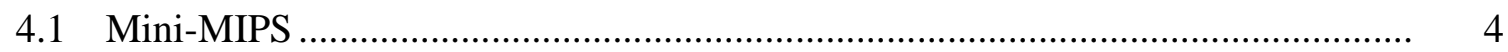

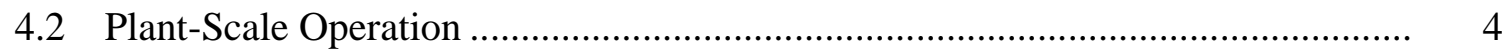

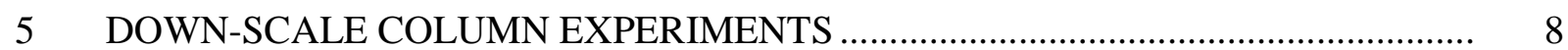

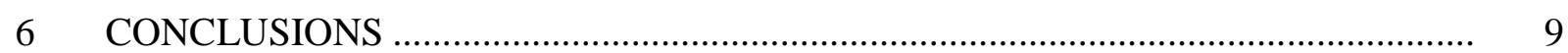

\section{FIGURES}

$1 \quad$ Kinetic Data for the Uptake of Mo from Solutions Containing 90 g-U/L Uranyl Sulfate or $150 \mathrm{~g}-\mathrm{U} / \mathrm{L}$ Uranyl Nitrate Using Pure Titania Sorbent with Different Particle and Pore Sizes

2 Dimensionless Stripping Results of Sachtopore Sorbents with $d_{p}=40,80$, and $110 \mu \mathrm{m}: 16.3 \mathrm{~cm} / \mathrm{min}$ for ID $=12.5 \mathrm{~cm} ; 12.3 \mathrm{~cm} / \mathrm{min}$ for ID $=14.4 \mathrm{~cm}$.

\section{TABLES}

1 Proposed Column Designs for MINI-MIPS 0.0045-mM Mo and 0.0055-mM Competing Ions in 145-g-U/L Uranyl Nitrate and 0.1-M Nitric Acid at $60^{\circ} \mathrm{C}$

2 Proposed Column Designs for the Plant-scale Process: $240 \mathrm{~L}$ of $0.0045-\mathrm{mM}$ Mo and 0.0055-mM Competing Ions in 145-g-U/L Uranyl Nitrate and 0.1-M

Nitric Acid Solution at $60^{\circ} \mathrm{C}$.

3 Results for Direct Down-scale Column Experiments for S110 and S40 


\section{COLUMN OPTIMIZATION STUDIES}

\section{INTRODUCTION}

Argonne National Laboratory (Argonne) is assisting Babcock and Wilcox Technical Services Group (BWTSG) in their efforts to develop an aqueous homogenous reactor (AHR) for the production of molybdenum-99 (Mo-99). Several different titania-based sorbents and alumina have been investigated as potential candidates for the development of a separation and recovery column for Mo-99 from a uranyl nitrate solution. A pure titania sorbent with $80-\mu \mathrm{m}$ particles and $60-\AA$ pores (S80) was initially chosen for the plant-scale column. However, ZirChrom

Separations, Inc., discontinued their Sachtopore (pure titania) sorbent with $80-\mu \mathrm{m}$ particles and 60 - $\AA$ pores. As a result, Argonne has tested several other Sachtopore sorbents with different particle and pore sizes in an effort to find a replacement for S80. Initial Versatile Reaction Separation (VERSE) column designs suggest that S40 is the best replacement for S80; however, experimental results show that a significant amount of Mo does not adsorb on the S40 sorbent. S110 performs much better than S40, and the S110 column designs are final designs for the plant-scale operation and the mini- Medical Isotope Production System (mini-MIPS). 


\section{BATCH STUDIES: EXPERIMENTAL}

The uptake of Mo(VI) was determined by equilibrating $1 \mathrm{~mL}$ of a Mo-99 spiked aqueous solution with a known amount $(10 \pm 1 \mathrm{mg})$ of sorbent for 24 hours or 1-48 hours for kinetic tests at $60^{\circ} \mathrm{C}$ using a thermostated shaker bath. Aqueous solutions contained tracer Mo-99 and $1 \mathrm{ppm}$ stable Mo added as $\mathrm{Na}_{2} \mathrm{MoO}_{4} \cdot 2 \mathrm{H}_{2} \mathrm{O}$ in the presence of uranyl nitrate. After equilibration, the solution was withdrawn and filtered using a syringe fitted with a $0.22-\mu \mathrm{m}$ pore size polyvinylidene fluoride (PVDF) membrane filter.

\subsection{PREPARATION OF Mo-99 SPIKE SOLUTION}

Mo-99 was obtained from a spent Tc-99m generator (provided by Hot Shots Nuclear Medicine), which we receive on a weekly basis. The initial activity of Mo-99 in a generator is typically between 1 and $10 \mathrm{Ci}$. However, we receive a Tc-99m generator when the activity remaining in the generator is insufficient for patient administration. Typically, a spent Tc-99m generator contains $0.1-0.3 \mathrm{Ci}$ of Mo-99, which is more than enough for our tracer batch and column work.

Mo-99 was removed from the generator by placing a serum vial containing $1 \mathrm{M} \mathrm{NH}_{4} \mathrm{OH}$ on the needle labeled "Saline Charge." After that, an evacuated serum vial was placed on the needle labeled "Receiver." When no more bubbles appeared in the Receiver vial, the Receiver bottle was removed from the generator. The Mo-99-spiked solution was prepared by bringing the solution to dryness on a hot plate, and re-dissolving it in $0.1-\mathrm{M} \mathrm{HNO}_{3}$.

\subsection{COUNTING OF Mo-99}

The amount of activity in the aqueous samples was determined using a germanium detector. Mo-99 was quantified by measurement of its $739 \mathrm{keV} \gamma$-ray. The activity of Mo-99 in each sample was corrected for decay. The extent of radionuclide uptake was expressed in terms of a distribution coefficient, $K_{d}$, shown in equation (1):

$$
K_{d}=\left(\frac{A_{o}-A_{s}}{W}\right) / \frac{A_{s}}{V} .
$$

Here, $A_{o}$ and $A_{s}$ represent the aqueous phase activity ( $\mu \mathrm{Ci}$ ) before and after equilibration, respectively; $W$ is the dry weight of the sorbent (g); and $V$ is the volume of the aqueous phase (mL). 


\section{KINETICS}

The uptake of Mo as a function of time was determined using a pure titania sorbent with different particle and pore sizes from solutions containing $90 \mathrm{~g}-\mathrm{U} / \mathrm{L}$ uranyl sulfate and $150 \mathrm{~g}-\mathrm{U} / \mathrm{L}$ uranyl nitrate. The pure titania sorbent with $110-\mu \mathrm{m}$ particles and 60 - $\AA$ pores (S110) performed the best. Mo uptake was fairly consistent using both $90 \mathrm{~g}-\mathrm{U} / \mathrm{L}$ uranyl sulfate and $150 \mathrm{~g}-\mathrm{U} / \mathrm{L}$ uranyl nitrate solutions after 1-40 hours of contact time using S110 sorbent. It appears that equilibrium has been reached after 40 hours using a $90 \mathrm{~g}$-U/L uranyl sulfate solution; however, it may take 48 hours or more for equilibrium to be reached using a $150 \mathrm{~g}-\mathrm{U} / \mathrm{L}$ uranyl nitrate solution. S80(60) performed the next best; however, the uptake of Mo was much better from a solution containing $150 \mathrm{~g}-\mathrm{U} / \mathrm{L}$ uranyl nitrate compared to a solution containing $90 \mathrm{~g}-\mathrm{U} / \mathrm{L}$ uranyl sulfate. S40(60) performed similarly to S80(60) in the presence of $90 \mathrm{~g}-\mathrm{U} / \mathrm{L}$ uranyl sulfate. Sorbents with larger pore sizes behaved much worse. S80(300), S40(300), and S80 (500) adsorbed the least amount of Mo, and the kinetics were slower. These results suggest that using a titania sorbent with larger pore sizes will not be a good choice for the design of a Mo separation and recovery column. $K_{d}$ values using titania sorbents with larger pore sizes are about 1000 times less after 20-48 hours of contact time. The effects of slower kinetics and decreased Mo adsorption are expected for solutions containing $150 \mathrm{~g}$-U/L uranyl nitrate, as well. The results are shown in Figure 1.

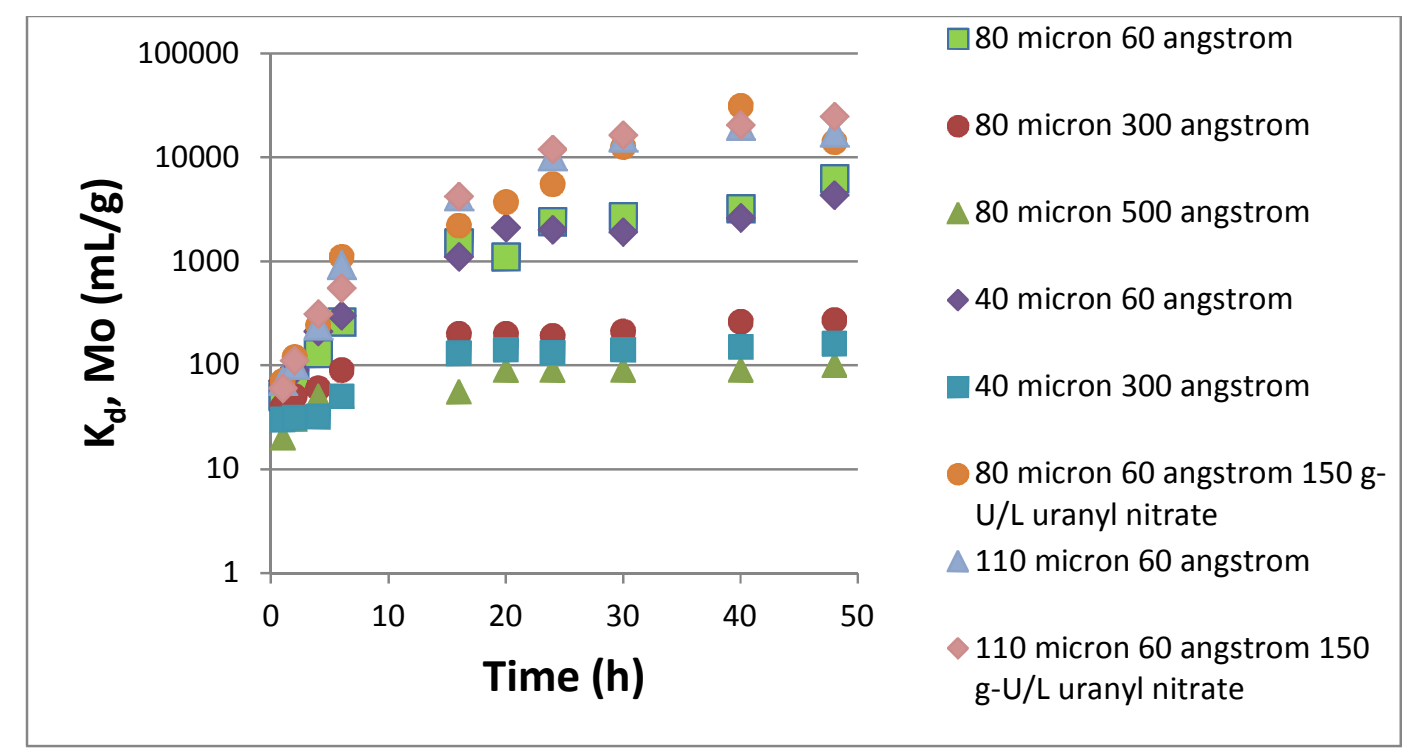

FIGURE 1 Kinetic Data for the Uptake of Mo from Solutions Containing $90 \mathrm{~g}-\mathrm{U} / \mathrm{L}$ Uranyl Sulfate or 150 g-U/L Uranyl Nitrate Using Pure Titania Sorbent with Different Particle and Pore Sizes 


\section{COLUMN DESIGN}

\subsection{MINI-MIPS}

Batch study data indicate that sachtopore sorbents with 40- and $110-\mu \mathrm{m}$ particles and 60 - $\mathrm{A}$ pores are suitable for the design of a separation and recovery column for Mo-99 for miniMIPS. As a result, batch study data were input into VERSE to generate column designs for S40 and S110. The mini-MIPS column design assumes a feed solution with a Mo concentration of $0.0045 \mathrm{mM}$ in the presence of $0.0055-\mathrm{mM}$ competing components. About $5 \mathrm{~L}$ of a $145 \mathrm{~g}-\mathrm{U} / \mathrm{L}$ uranyl nitrate solution ( $\mathrm{pH} 1)$ will be loaded onto a column in 2 hours in the up-flow direction. Mo will be eluted in the down-flow direction using 1- $\mathrm{M} \mathrm{NH}_{4} \mathrm{OH}$, and VERSE assumes 99\% recovery. The pressure limit is set at 0.8 atmospheres. Table 1 shows the column designs for the mini-MIPS solution for S40, S80, and S110. Each column will have an internal diameter of $2.0 \mathrm{~cm}$, but the minimum length that should be tested (as indicated by VERSE results) varies for each sorbent: $\mathrm{S} 40-3.5 \mathrm{~cm}$; $\mathrm{S} 80-6.8 \mathrm{~cm}$; and $\mathrm{S} 110-9.8 \mathrm{~cm}$. The loading velocities do not change and are set at $12.3 \mathrm{~cm} / \mathrm{min}$. Based on the results shown in Table 1, S40 appears to be the top candidate.

\subsection{PLANT-SCALE OPERATION}

Batch study data indicate that Sachtopore sorbents with $40-$ and $110-\mu \mathrm{m}$ particles and 60 - $\AA$ pores are suitable for the design of a separation and recovery column for Mo-99 for the plant-scale process. As a result, batch study data were input into VERSE to generate column designs for S40 and S110. The plant-scale column design assumes a feed solution with a Mo concentration of $0.0045 \mathrm{mM}$ in the presence of $0.0055 \mathrm{mM}$ competing components.

Approximately $240 \mathrm{~L}$ of a $145 \mathrm{~g}-\mathrm{U} / \mathrm{L}$ uranyl nitrate solution (pH 1) will be loaded onto a column in 2 hours in the up-flow direction. Mo will be eluted in the down-flow direction using $1-\mathrm{M} \mathrm{NH}_{4} \mathrm{OH}$, and VERSE assumes $99 \%$ recovery. The pressure limit is set at $0.8 \mathrm{~atm}$. Two different linear velocities $(16.3 \mathrm{~cm} / \mathrm{min}$ and $12.3 \mathrm{~cm} / \mathrm{min})$ and internal diameters $(14.4 \mathrm{~cm} / \mathrm{min}$ and $12.5 \mathrm{~cm} / \mathrm{min}$ ) were tested for each sorbent using VERSE. VERSE stripping results are shown in Figure 2. Table 2 shows the column designs for the plant-scale process for S40, S80, and S110. Again, results suggest that S40 would be the top candidate for the Mo-99 separation and recovery column because it would be the smallest column. The $14.4-\mathrm{cm} \mathrm{ID} \times 3.5-\mathrm{cm} \mathrm{L}$ column design for S40 would be the smallest column, but the $12.5-\mathrm{cm} \mathrm{ID} \times 4.6-\mathrm{cm} \mathrm{L} \mathrm{column}$ design for S40 exceeds the pressure limit of $0.8 \mathrm{~atm}$. 
TABLE 1 Proposed Column Designs for MINIMIPS 0.0045-mM Mo and 0.0055-mM Competing Ions in 145-g-U/L Uranyl Nitrate and 0.1-M Nitric Acid at $60^{\circ} \mathrm{C}$ (loading time $=2$ hours, up-flow), 1-M NH $\mathrm{NH}_{4} \mathrm{OH}$ Stripping for $\mathbf{9 9 \%}$ Mo Recovery (down-flow)

\begin{tabular}{|c|c|c|c|}
\hline \multirow[b]{2}{*}{ Parameter } & \multicolumn{3}{|c|}{ Mini-MIPS } \\
\hline & $\mathrm{S} 40$ & S80 & S110 \\
\hline$d_{p}(\mu \mathrm{m})$ & 40 & 80 & 110 \\
\hline $\mathrm{ID}(\mathrm{cm})$ & 2.0 & 2.0 & 2.0 \\
\hline$u_{s, \text { loading }}(\mathrm{cm} / \mathrm{min})$ & 12.3 & 12.3 & 12.3 \\
\hline$L_{\max }(\mathrm{cm})^{\mathrm{a}}$ & 4.6 & 18.2 & 34.3 \\
\hline$L_{\min }(\mathrm{cm})^{\mathrm{a}}$ & 1.7 & 3.4 & 4.9 \\
\hline \multicolumn{4}{|c|}{ Designs with min. $L_{\text {tested }}$} \\
\hline Min. $L_{\text {tested }}{ }^{\mathrm{a}}(\mathrm{cm})$ & 3.5 & 6.8 & 9.8 \\
\hline$C V_{\text {tested }}(\mathrm{mL})$ & 5 & 11 & 15 \\
\hline Flowrate (mL/min) & 38.6 & 38.6 & 38.6 \\
\hline Feed Vol. (mL) & 4636 & 4636 & 4636 \\
\hline$\Delta P(\mathrm{~atm})$ & 0.6 & 0.3 & 0.2 \\
\hline$W_{\text {sorbent }}(\mathrm{g})$ & 7 & 14 & 20 \\
\hline \multicolumn{4}{|l|}{ Stripping ${ }^{\mathrm{b}}$} \\
\hline$u_{s}(\mathrm{~cm} / \mathrm{min})$ & 10.0 & 10.0 & 10.0 \\
\hline Vol. (mL) & 41 & 103 & 164 \\
\hline Vol. (CV) & 3.8 & 4.8 & 5.3 \\
\hline Time (min) & 1.7 & 4.2 & 6.6 \\
\hline
\end{tabular}

a At a given velocity, $L_{\max }$ is the column length when pressure drop during loading is $0.8 \mathrm{~atm} ; L_{\min }$ is column length from column inlet to the leading edge of $0.1 \% C_{f, M o}$. The minimum $L_{\text {tested }}$ has a safety factor of 2: a capture column with $L_{0.1 \% C f, M o}$ and a guard column with $L_{0.1 \% C f, M o}$.

b The stripping step starts at the $\mathrm{pH}$ step change and lasts until $99 \%$ Mo is recovered. 

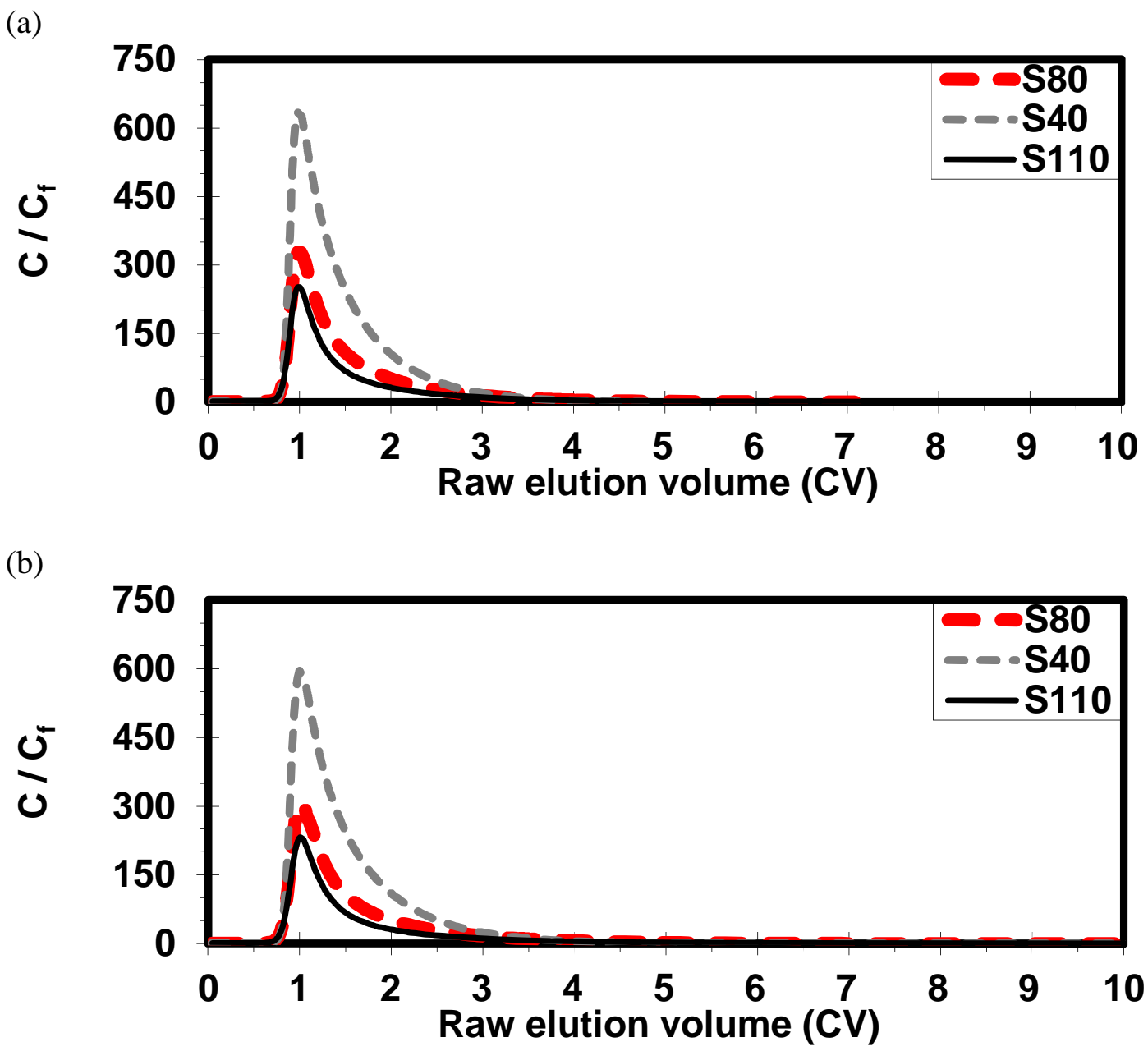

FIGURE 2 Dimensionless Stripping Results of Sachtopore Sorbents with $d_{p}=40$ (S40), 80 (S80), and $110 \mu \mathrm{m}$ (S110): (a) $16.3 \mathrm{~cm} / \mathrm{min}$ for ID = $12.5 \mathrm{~cm}$; (b) $12.3 \mathrm{~cm} / \mathrm{min}$ for ID $=14.4 \mathrm{~cm}$ 
TABLE 2 Proposed Column Designs for the Plant-scale Process: $240 \mathrm{~L}$ of 0.0045-mM Mo and 0.0055-mM Competing Ions in 145-g-U/L Uranyl Nitrate and 0.1-M Nitric Acid Solution at $60^{\circ} \mathrm{C}$ (loading time $=2$ hours; flow rate $=2.0 \mathrm{~L} / \mathrm{min}$, up-flow $)^{\mathrm{a}}$

\begin{tabular}{|c|c|c|c|c|c|c|c|c|c|c|c|c|c|c|}
\hline \multirow{2}{*}{\multicolumn{2}{|c|}{ ID }} & \multirow[b]{3}{*}{ Sorbent } & \multirow[b]{3}{*}{$d_{p}(\mu \mathrm{m})$} & \multirow[b]{3}{*}{$L_{\max }(\mathrm{cm})^{\mathrm{b}}$} & \multirow[b]{3}{*}{$\begin{array}{c}L_{\min } \\
(\mathrm{cm})^{\mathrm{b}}\end{array}$} & \multicolumn{4}{|c|}{ Plant Designs with min. $L_{\text {plant }}$} & \multicolumn{5}{|c|}{$\begin{array}{l}\text { 1-M Stripping (down flow) for } 99 \% \text { Mo } \\
\text { Recovery }^{c}\end{array}$} \\
\hline & & & & & & \multirow{2}{*}{$\begin{array}{l}\text { Min. } \\
L_{\text {plant }} \\
(\mathrm{cm})\end{array}$} & \multirow[b]{2}{*}{$\begin{array}{c}\Delta P \\
(\mathrm{~atm})\end{array}$} & \multirow[b]{2}{*}{$C V(\mathrm{~L})$} & \multirow[b]{2}{*}{$\begin{array}{l}W_{\text {sorbent }} \\
(\mathrm{kg})\end{array}$} & \multirow[b]{2}{*}{ Solution } & \multirow[b]{2}{*}{$\begin{array}{c}u_{s} \\
(\mathrm{~cm} / \mathrm{min}) \\
\end{array}$} & \multirow[b]{2}{*}{$\begin{array}{c}\text { Vol. } \\
(\mathrm{L})\end{array}$} & \multirow[b]{2}{*}{$\begin{array}{l}\text { Vol. } \\
(\mathrm{CV})\end{array}$} & \multirow[b]{2}{*}{$\begin{array}{l}\text { Time } \\
(\min ) \\
\end{array}$} \\
\hline$(\mathrm{cm})$ & (in.) & & & & & & & & & & & & & \\
\hline 12.5 & 4.9 & $\mathrm{~S} 40$ & 40 & 3.4 & 2.3 & 4.6 & 1.1 & 0.28 & 0.36 & $\mathrm{NH}_{4} \mathrm{OH}$ & 16.3 & 1.9 & 3.4 & 2.0 \\
\hline 12.5 & 4.9 & $\mathrm{~S} 80$ & 80 & 13.7 & 4.5 & 9.0 & 0.5 & 0.55 & 0.71 & $\mathrm{NH}_{4} \mathrm{OH}$ & 16.3 & 4.7 & 4.2 & 4.8 \\
\hline 12.5 & 4.9 & S110 & 110 & 25.8 & 6.4 & 12.9 & 0.4 & 0.79 & 1.03 & $\mathrm{NH}_{4} \mathrm{OH}$ & 16.3 & 7.3 & 4.6 & 7.6 \\
\hline 14.4 & 5.7 & $\mathrm{~S} 40$ & 40 & 4.6 & 1.7 & 3.5 & 0.6 & 0.28 & 0.37 & $\mathrm{NH}_{4} \mathrm{OH}$ & 12.3 & 2.1 & 3.8 & 1.7 \\
\hline 14.4 & 5.7 & S80 & 80 & 18.2 & 3.4 & 6.8 & 0.3 & 0.56 & 0.72 & $\mathrm{NH}_{4} \mathrm{OH}$ & 12.3 & 5.3 & 4.8 & 4.2 \\
\hline 14.4 & 5.7 & S110 & 110 & 34.3 & 4.9 & 9.8 & 0.2 & 0.80 & 1.04 & $\mathrm{NH}_{4} \mathrm{OH}$ & 12.3 & 8.5 & 5.3 & 6.6 \\
\hline
\end{tabular}

a $\quad$ Shaded text indicates that $\Delta P>0.8$ atm.

b At a given velocity, $L_{\max }$ is the column length when pressure drop during loading $=0.8 \mathrm{~atm} ; L_{\min }$ is column length from column inlet to the leading edge of $0.1 \% C_{f, M o}$. The minimum $L_{\text {plant }}$ has a safety factor of 2: a capture column with $L_{0.1 \% C f, M o}$ and a guard column with $L_{0.1 \% C f, M o}$.

c The stripping step starts from $\mathrm{pH}$ step change and ends until $99 \%$ Mo is recovered. 


\section{DOWN-SCALE COLUMN EXPERIMENTS}

Results for down-scale column experiments for S40 and S110 are shown in Table 3. The feed solution contained 0.0045-mM stable Mo and tracer Mo-99 and 145-g-U/L uranyl nitrate. Linear velocities ranged from 3 to $9 \mathrm{~cm} / \mathrm{min}$, but results do not show an effect of linear velocity on Mo recovery. A significant amount of Mo is observed in the effluent at linear velocities of 5 and $9 \mathrm{~cm} / \mathrm{min}(16-32 \%)$ for S40. This suggests that S40 would not be the best replacement for S110, despite the fact that VERSE predicted smaller column designs for S40. About 1-2\% Mo is found in the effluent using S110, and recoveries vary from 73-89 $\pm 5 \%$ using 30 column volumes $(\mathrm{CVs})$ of $1-\mathrm{M} \mathrm{NH}_{4} \mathrm{OH}$. Better temperature control of the feed solution $\left(60-80^{\circ} \mathrm{C}\right)$ is expected in improve Mo adsorption on titania. Potassium permanganate was added to the water washes to ensure Mo was present as Mo(VI) for the runs performed on October 6, 2011, and October 12, 2011. Mo recovery results do not improve under these conditions when an oxidizing agent such as $\mathrm{KMnO}_{4}$ is added.

TABLE 3 Results for Direct Down-scale Column Experiments for S110 and S40

\begin{tabular}{|c|c|c|c|c|c|c|c|}
\hline $\begin{array}{c}\text { Date of } \\
\text { Run }\end{array}$ & $\begin{array}{l}\text { Column Size } \\
(\mathrm{ID} \times \mathrm{L})\end{array}$ & $\begin{array}{l}\text { Velocity } \\
(\mathrm{cm} / \mathrm{min}) \\
\end{array}$ & Sorbent & $\begin{array}{l}\% \text { Mo in } \\
\text { Effluent }\end{array}$ & $\begin{array}{l}\% \text { Mo in } \\
\text { Washes }\end{array}$ & $\begin{array}{c}\% \mathrm{Mo} \\
\text { Recovered } \\
\end{array}$ & $\begin{array}{c}\text { Stripping } \\
\text { Agent }\end{array}$ \\
\hline 09/15/11 & $1.5 \times 3.1$ & 9 & $\mathrm{~S} 40$ & 16.0 & 0.6 & 86.0 & $1 \mathrm{M} \mathrm{NH}_{4} \mathrm{OH}$ \\
\hline 09/21/11 & $1.5 \times 6.2$ & 3 & S110 & 1.0 & 0.6 & 88.0 & $1 \mathrm{M} \mathrm{NH}_{4} \mathrm{OH}$ \\
\hline $09 / 23 / 11$ & $1.5 \times 6.3$ & 5 & S110 & 1.0 & 1.0 & 85.0 & $1 \mathrm{M} \mathrm{NH}_{4} \mathrm{OH}$ \\
\hline $09 / 26 / 11$ & $1.5 \times 2.6$ & 5 & $\mathrm{~S} 40$ & 32.0 & 0.3 & 80.0 & $1 \mathrm{M} \mathrm{NH}_{4} \mathrm{OH}$ \\
\hline 09/28/11 & $1.5 \times 6.3$ & 10 & S110 & 1.0 & 0.1 & 77.0 & $1 \mathrm{M} \mathrm{NH}_{4} \mathrm{OH}$ \\
\hline 09/30/11 & $1.5 \times 6.3$ & 7.5 & $\mathrm{~S} 110$ & 2.0 & 0.1 & 85.0 & $1 \mathrm{M} \mathrm{NH}_{4} \mathrm{OH}$ \\
\hline $10 / 06 / 11$ & $1.5 \times 6.2$ & 7.5 & S110 & 7.3 & 0.8 & $73.0^{\mathrm{a}}$ & $1 \mathrm{M} \mathrm{NH}_{4} \mathrm{OH}$ \\
\hline $10 / 12 / 11$ & $1.5 \times 6.2$ & 3 & S110 & 7.0 & 1.0 & $89.0^{\mathrm{a}}$ & $1 \mathrm{M} \mathrm{NH}_{4} \mathrm{OH}$ \\
\hline
\end{tabular}

a $\quad 0.5$ wt. $\% \mathrm{KMnO}_{4}$ added to first water wash for these runs. 


\section{CONCLUSIONS}

Final column designs for the BWTSG plant-scale operation and mini-MIPS will utilize S110 sorbent with $60-\AA$ pores. VERSE column designs suggest that S40 is the best replacement for S80, but experimental results show that S110 outperforms S40. The final column design for mini-MIPS is a $2.0-\mathrm{cm}$ ID $\times 9.8-\mathrm{cm} \mathrm{L}$ column where $5 \mathrm{~L}$ of solution will pass through the column at a linear velocity of $12.3 \mathrm{~cm} / \mathrm{min}$. The final plant-scale column design is a 14.4-cm ID $\times 9.8-\mathrm{cm} \mathrm{L} \mathrm{column} \mathrm{where} 240 \mathrm{~L}$ of solution will pass through the column at a linear velocity of $12.3 \mathrm{~cm} / \mathrm{min}$. Results from mini-MIPS should tell us if an oxidizing agent such as $\mathrm{KMnO}_{4}$ is needed to ensure $\mathrm{Mo}(\mathrm{VI})$ is not reduced upon irradiation. 



\section{Argonne}

Chemical Science and Engineering Division

Argonne National Laboratory

9700 South Cass Avenue, Bldg. 205

Argonne, IL 60439-4837

www.anl.gov 